DOI 10.31554/978-5-7925-0530-8-2018-175-184

ФИЛОСОФСКО-РЕЛИГИОЗНЫЕ ТЕЧЕНИЯ В КИТАЕ В ПЕРИОД РАСПРОСТРАНЕНИЯ БУДДИЗМА ${ }^{109}$

Орбодоева Марина Валерьевна кандидат исторических наук,

отдел философии, культурологи и религиоведения, Институт монголоведения, буддологии и тибетологии Сибирского отделения Российской академии наук, г. Улан-Удэ

E-mail: orbodoevamv@yandex.ru

В данной статье рассматриваются философско-религиозные течения, которые существовали в период распространения буддизма в Китае, дается анализ таких течений как фэнлю, цинтань, сюаньсюэ.

Ключевые слова: буддизм, фэн лю, цин тань, сюань сюэ, становление, взаимовлияние.

\title{
PHILOSOPHICAL-RELIGIOUS TRENDS IN CHINA DURING THE SPREAD OF BUDDHISM
}

Orbodoeva Marina $V$.

CSc in History

Department of Philosophy, Cultural and Religious Studies Institute for Mongolian, Buddhist and Tibetan Studies, Siberian Branch of the Russian Academy of Science, Ulan-Ude, Russia

E-mail: orbodoevamv@yandex.ru

This article examines the philosophical and religious trends that existed during the period of Buddhism in China. Also in the article there is an analysis of such trends as Feng Liu, Qing Tan, Xuan Xue.

Keywords: Buddhism, Feng Liu, Qing Tang, Xuan Xue, formation, mutual influence.

Становление и распространение буддизма в Китае происходило в непростой для страны период, последовавший после крушениz империи Хань (206 до н. э. - 220 н. э.), обусловивший повсеместный хаос, разруху и нестабильность. Такое положение в стране отразилось и на идеологической ситуации, для которой были характерны идеи

\footnotetext{
${ }^{109}$ Статья подготовлена в рамках гранта РФФИ № 17-03-00250 «Философская интерпретация и трансляция буддизма (на материале тибетской и китайской махаяны)».
} 
отрешенности от социальных, политических реалий и экономических неурядиц. Менялись стереотипы древних классических учений конфуцианства и даосизма.

Обстановка нестабильности, постоянных внутренних войн и набегов способствовала росту популярности отшельничества, бегства от суетности повседневной жизни, большую популярность приобретала медитация. В аристократической и интеллектуальной среде получает распространение особый стиль жизни «ветра и потока» (фэн лю, 风 流), характеризующийся демонстративной отрешенностью от политических дел и повседневных забот, нарочитым равнодушием к богатству и почестям. Как пишет Т. Г. Степугина, «название 风流 фэн лю «ветер и поток» символизирует непостоянство, изменчивость и гибкость природных стихий. Человек уподобляется им, раскрывая свою собственную природу, следуя естественности (自然 цзыжань) и недеянию (无为 у-вэй). Представителей этого течения называли минши 名士, что можно перевести как «славные мужи», «знаменитые мужи», «знаменитости»» [История Востока, 2002, с. 81].

Их философия ярко выражена в следующих словах:

«Жизнь - это плывущее бревно: она появляется на мгновение и внезапно исчезает. Заботы и дела мира беспорядочны и запутаны. Забудем о них. Даже на болотах голодный фазан не мечтает о парках. Как могу я служить, утомляя свое тело и печаля свое сердце? Высоко ценят тело, а пустое имя презирают. Нет ни славы, не бесчестия. Самое важное - следовать своей воле и без раскаяния освободить свое сердце» [цит. Елисеефф, 2007, с.52].

В этих словах видно глубокое разочарование в официальной культуре, в тех установках, которые предписывались официальным конфуцианством. Представители «фэн лю» считали что, жизнь одна и надо прожить её в своё удовольствие. Это были попытки поиска альтернативы конфуцианству с его идеалом служения государству и обществу.

Выражение своей природы «славными мужами» мин-ши (名士) заключалось в эксцентричном поведении, стремлении к чувственным удовольствиям, неприятии общепринятых ценностей. И в то же время они стремились к духовному совершенствованию, были умны и образованны, стремились к познанию себя и мира. Они обладали 
утонченным вкусом, чутко реагировали на все происходящее вокруг и ценили красоту. Их утонченные разговоры получили название «чистых бесед» (цин тань, 清谈).

«Славные мужи» следовали своим желаниям, говорили и делали то, что подсказывало им сердце, даже если со стороны это казалось неразумным. Они охотно выражали свои чувства, открыто говорили о дружбе, любви или неприязни к кому-либо, хотя в последнем случае старались выбирать наиболее изысканные и утонченные слова, отдавая дань старой китайской традиции остроумной насмешки и тонкого намека [Анашина, эл. ресурс].

С другой стороны, были и такие, кто вслед за Чжуан-цзы считали, что «совершенномудрый не имеет эмоций» и изменения и превращения вещей не трогают его. Один из авторов того времени, Лю Ицин, рассказывая в своей книге «Новое изложение рассказов, в свете ходящих» о Се Ане (320-385), занимавшем пост первого министра при династии Цзинь (265-420) пишет:

«В 393 г. армия северной лже-династии Цинь начала широкомасштабное наступление на Цзинь. Ее вел сам император, который хвалился, что она так многочисленна, что «стоит моим воинам бросить свой хлыст в Янцзы, и они запрудят реку». Люди Цзинь были встревожены. Се Ань спокойно приказал своему племяннику Се Сюню повести армию в наступление. В битве на реке Фэй Се Сюнь одержал победу, остатки армии Цинь бежали. Когда к Се Аню прибыл гонец, он играл с другом в шахматы. Он открыл письмо, прочитал его и, как ни в чем не бывало, продолжил играть. Когда друг спросил о новостях, Се Ань тихо и сдержанно ответил: “Наша армия полностью разгромила врага” (гл. 6)» [Лю Ицин «Новое изложение рассказов, в свете ходящих». Цит. по: Анашина, эл. ресурс].

Многие из них называли свои творения «совершенными», как, например, родоначальник пейзажной живописи Гу Кайчжи, и «уникальными», как основоположник теории стихосложения Шэнь Юэ. «Безмерно гордился собой Се Линъюнь, не отличался ложной скромностью и поэт Бао Чжао». Другие же, напротив, предавались самоуничижению, не пытаясь скрыть собственные пороки: «Я не читаю классических книг, по натуре небрежен и ленив, медлителен в движениях», - говорит о себе Цзи Кан [о Цзи Кане см. Там же]. 
Отказавшись от активной социальной и политической деятельности, «мудрецы» уделяли все свое внимание саморазвитию. Во время таких дружеских встреч они старались достичь состояния такой внутренней свободы, при которой теряют значение правила ритуала и социальные догмы. Веселясь и напиваясь допьяна, поэты испытывали творческое вдохновение и начинали с большей легкостью предаваться философским изысканиям.

«Славные мужи» стирали границы между собой и миром природы. Они стремились к уходу от мирской суеты и отшельничеству, жизни в окружении природы, пусть и не всегда это удавалось реализовать в жизни. Теме вина посвящены стихи знаменитого поэта Тао Юаньминя (陶渊明, 365-427), о котором современники говорили, что «в стихах его вино льется, с вином у него стих поется». Он написал замечательное стихотворение «За вином» (досл. «Пить вино» 饮酒), вот отрывок из него в переводе Л. Эйдлина:

«Все мы смертны. Ужели тебя не прельщает вино?

Вспомни, друг мой, о предках - их нету на свете давно»

[Классическая поэзия, 1972].

В этих строках выражена мысль о скоротечности жизни и о том,почему бы не насладиться вином, пока ты жив. В стихотворениях того времени часто проскальзывают мотивы любования своим домом, родным краем, Вот, например, отрывок из Се Тяо под названием «То, что было в меня на душе в свободное от дел время», в переводе Л. Бадылкина:

«На свете, говорят, десятки тысяч гор,

Но холмиком одним не налюбуюсь я.

Здесь, у крыльца, есть все, что радует мой взор,

И не влечет меня в далекие края».

[Там же, с. 464-496].

Мин-ши часто навещали даосских отшельников, но далеко не все из них хотели ими становиться. Сама идея одиночества, разлуки с друзьями была неприемлема для них.

В западной синологии фэн лю часто рассматривали как альтернативу конфуцианству. Конфуцианские ценности, такие как «сыновняя почтительность» и «отцовская любовь», преданность государю, 
любовь к музыке присутствовали в жизни «славных мужей». Однако они более открыто, чем было принято, выражали свои чувства, не стесняясь их.

Философским обоснованием фэн лю стало направление сюань-сюэ (玄学, «Учение о сокровенном»). Идеалом становится человек, «обладающий разумом и духом, вырывающийся за пределы разграничения вещей и живущий в согласии с самим собой, а не с другими». Философы Сян Сю (227-272 гг.) и Го Сян $(252-312$ гг.) в комментариях к «Чжуан-цзы» писали, что каждая отдельная вещь является результатом взаимодействия и взаимопроникновения различных вещей в ходе непрерывного процесса космических превращений. И если сложившийся порядок вещей будет насильственно кем-то нарушен, то человек (или любое другое существо или вещь) может не родиться на свет или проживет меньше отпущенного ему срока.

Недеяние, с их точки зрения, вовсе не означает «ничего неделание», это спонтанное и естественное действие - «без сучка и задоринки»: не делать ничего лишнего - не «пририсовывать змее ноги» и не «тянуть всходы, чтобы помочь им вырасти». Проблема человека заключается в том, что он начинает приспосабливать вещи к своим нуждам и диктовать им свою волю, вместо того, чтобы дать им быть такими, какие они есть. «Так, люди заставляют быстрых лошадей скакать медленнее, а медленных - быстрее. Не нужно бросать поводья и позволить делать все, что хочется. Следует действовать в соответствии с природой - использовать быстрого коня там, где нужна быстрая езда, а медленного - для езды неторопливой» [цит. по: Анашина, эл. ресурс].

Художников и поэтов III-VI веков определенно нельзя обвинить в чрезмерной деятельности: их излюбленным занятием было собираться в тенистых садах, декламировать стихи и вести философские «чистые беседы» (цинтань, 清谈). В. В.Малявин пишет об этом времени так: «Несмотря на обстановку смутного времени, а может быть, как раз благодаря ей, то был период замечательных достижений в области духовной культуры. Ярким, неповторимым колоритом отличается интеллектуальная жизнь того времени: увлечение вопросами метафизики, для обсуждения которых устраивались свободные 
ученые дискуссии, так называемые «Чистые беседы» (кит. цин тань) [Малявин, 1987, с.8].

«Чистые беседы» (цинтань) - это течение философской и общественной мысли, объединявшее философов, поэтов, писателей и других представителей интеллигенции. «Чистым беседам» было свойственно обсуждение как даосских, так и конфуцианских проблем. Обсуждались вопросы внутренней свободы человека в духе даосских идеалов и одновременно вопросы соединения идеалов внутренней свободы с ценностями чиновника-конфуцианца; вопросы метафизики и вопросы этики; вопросы общественные и вопросы политические. Сторонники цинтань не были единомышленниками, их состав был довольно пестрым. По духовному родству они объединялись в кружки, наиболее известным из которых был кружок «Семи мудрецов из бамбуковой рощи» (кит. Чжулинь ци сянь), объединивший известнейших мыслителей и поэтов. В их число входили Жуань Цзи (210-263), Цзи Кан (223-262), Сян Сю (227-272), Жуань Сянь (III в.), Лю Лин (225-280), Шань Тао (205-283) и Ван Жун (234-305).

«Семь мудрецов из бамбуковой рощи» - это самый известный в Китае того времени философский кружок. Как сказано выше, в него входили известные философы и поэты. Они собирались в бамбуковой роще, вели учёные беседы, пили вино и музицировали. «Историки считают их литературными гениями, они положили начало метафизической философии, а также были непревзойдёнными в искусстве каллиграфии» [Судникович, эл. ресурс].

Это был период поисков новых идей, нового отношения к традиционной философии. Из когорты мыслителей «Чистых бесед» вышли философы школы сюань сюэ - учения о сокровенном, оказавшем огромное влияние на становление праджняпарамитских традиций в Китае [Малявин,1974].

В Китае существовал культ древности, т. е. чем старше и древнее то или иное учение, тем оно «правильнее». По словам Л. Е. Янгутова, именно культ древности «обусловил одну из самых характерных особенностей китайской философии - ее консервативность и традиционность, обеспечивающих высокую степень преемственности: обсуждение одних и тех же проблем, использование одних и тех же категорий на протяжении многих веков» [2007].

Философы Китая смогли передать новые мысли и идеи, выразив их в старой форме. Л. Е. Янгутов продолжает эту мысль: «Такое 
отношение к традиционному наследию определило своеобразие развития китайской философии в период Вэй и двух Цзинь, выразившееся в преимуществе комментаторского творчества в литературной деятельности китайских мыслителей. В своих комментариях к древним канонам они имели возможность, не опровергая старые идеи, выдвигать собственные, объясняя их как пояснение глубокого смысла учения древних авторитетов» [Там же].

В комментаторском творчестве философов Вэй и двух Цзинь внимание акцентировалось на онтологических аспектах даосских канонов. Постепенно происходил поворот от космологической проблематики к онтологической. Развитие комментаторской деятельности, направленной на онтологизацию космологических проблем даосизма, привело к формированию в период Вэй и Цзинь школы сюань сюэ.

Л. Е. Янгутов подчеркивает, что учение сюаньсюэ (玄学) оформилось в форме комментариев на классические каноны не только даосизма «Дао дэ цзин» и «Чжуан-цзы», но и конфуцианства «Чжоу и» и «Лунь юй». Его формирование явилось реакцией на социальнополитическую и философско-мировоззренческую обстановку в Китае после крушения империи Хань и образования на ее месте трех государств.

Другой известный российский синолог Е. А. Торчинов писал, что реакцией учения сюань сюэ на социально-политическую обстановку явился ее новый подход к оказавшемуся в глубоком кризисе официальному конфуцианству за счет внесения в него даосской проблематики, а реакцией на философско-мировоззренческую ситуацию - онтологизация космологических представлений даосизма [Торчинов, 1993, с. 68]. Соглашаясь с ним, Л. Е. Янгутов развивает эту мысль далее, усматривая именно в онтологии близость буддизма традиционным китайским представлениям. Он пишет: «И именно эта онтологическая часть даосской философии стала наиболее привлекательной для буддистов, обнаруживших в ней множество точек соприкосновения с праджняпарамитской концепцией пустоты» [2007].

Основателями школы сюань сюэ являются Ван Би (226-249) и Хэ Янь (190-249). Ван Би, несмотря на свою молодость и короткую жизнь, оставил в философском наследии более глубокий след, чем Хэ Янь. Согласно сведениям из династической истории «Сань го чжи», 
«Хэ Янь был поражен выдающимися способностями и умом молодого Ван Би и при знакомстве воскликнул: “Этот человек сможет говорить и о небе и о человеке!"» [цит. по: Петров, 1936, с. 19]. В китайских исторических хрониках сохранилось мало сведений относительно жизни и творчестве Ван Би. Слишком краткой была его жизнь, не успел он занять высокое положение и звание. Резюмируя эти сведения, А. А. Петров в монографическом исследовании творчества Ван Би сообщает: «Ван Би - второе имя Фу Сы - родился в седьмом году правления под девизом Хуан-чу императора династии Вэй-Вэньди (Цао Пэй - сын Цао Цао) или в 226 г. нашей эры в царстве Вэй (в уезде Шань-ян, на территории нынешней провинции Цзянсу). По свидетельству современников, Ван Би уже в юношеском возрасте обнаружил исключительные способности, большую любознательность и проницательный ум. Особенно он любил рассуждать о принципах даосизма, подвергал их дискутированию в среде своих друзей и выделялся среди них своей начитанностью в классических книгах. В годы правления чжэн-ши при императоре Фэй-ди (240 г. н. э.) Ван Би служил в центральных придворных учреждениях государства Вэй, работая и развиваясь таким образом в окружении придворной феодальной бюрократии, к числу которой нужно отнести и его самого. Круг его знакомых состоял из образованных чиновниковлитераторов того времени, среди которых упоминаются Пэй Хуй, Фу Гу, Хэ Янь, Цао Шуан» [Петров, 1936, с.19] .

А. И. Кобзев пишет про деятельность Ван Би: «Стремясь обосновать конфуцианские взгляды на общество и человека с помощью даосской метафизики, а не натурфилософии своих предшественников - конфуцианцев эпохи Хань (III в. до н. э. - III в. н. э.), Ван Би выработал систему категорий, оказавшую в дальнейшем значительное влияние на понятийный аппарат и концепции китайского буддизма и неоконфуцианства» [Духовная культура Китая, 2006] .

Известный китайский буддолог Хун Сюпин пишет в своей статье: «В период Вэй и Цзинь учение сюаньсюэ достигло полного расцвета. С точки зрения теории, сюаньсюэ - это синтез конфуцианства и даосизма, оно явилось теоретическим поиском путей гармоничного развития общества и устроения спокойной жизни в такой особый период, как период династий Вэй и Цзинь. Важной особенностью 
этого поиска было разъяснение конфуцианства посредством даосского учения и сообразование с Дао на основе конфуцианства. Можно сказать, что сюаньсюэ - это синтез конфуцианства и даосизма на основе даосской натурфилософии, как базовой конструкции. Философский дух этого учения был близок к даосизму и сформировал конфуцианский идеал общественной жизни. Поэтому синтез сюаньсюэ и буддизма связан с синкретическим триединым учением конфуцианства, буддизма и даосизма. А синтез буддизма с сюаньсюэ был внутренней потребностью развития буддийского учения, это связано с эволюцией китайской культуры мысли»[Хун Сюпин, 2016, c. 68-77].

Резюмируя вышесказанное, необходимо отметить, что возникновение учения сюань сюэ явилось логическим следствием развития философско-мировоззренческой мысли китайцев в эпоху Вэй. В новых исторических условиях возникла необходимость пересмотра конфуцианской и даосской философии, преодоления их противостояния. С другой стороны, на развитие философско-мировоззренческой мысли стало оказывать влияние проникающее в Китай буддийское учение о Праджняпарамите (боже, 般若), которое китайцы воспринимали во многом сходным с даосской философией. В эпоху Вэй наметился синтез трех учений конфуцианства, даосизма и буддизма. И, как отметил Хун Сюпин, этот синтез был основан на «даосской натурфилософии, как базовой конструкции». Поэтому учение сюаньсюэ в основном отражало идеи даосизма. Учение сюаньсюэ во многом облегчило восприятие китайцами буддийской философии. И, как отметил Л. Е. Янгутов, «взаимодействие буддизма с даосизмом, о котором часто говорится в научной литературе, по сути есть взаимодействие сюаньсюэ и праджняпарамиты» [2007, с.75].

Указанное выше новое видение мира неотделимо от тех кардинальных изменений в идеологии, которые произошли в отмеченный период. Таким образом, сложившиеся течения цинтань, сюаньсюэ, фэньлю и др. стали характерным отражением той ситуации, которая сложилась после падения империи Хань, девальвации прежних социальных и культурных ценностей и формирования новых политических отношений. Эти учения оказались во многом близки по духу проникающему в Китай новому иноземному учению - буддизму, который провозглашал идею иллюзорности внешнего мира и 
спасения не в настоящей жизни, а в будущем перерождении, в нирване. Подобное созвучие буддийских идей настроениям рассматриваемой эпохи во многом стало причиной успеха буддизма в Китае.

\section{Литература}

Анашина М. Фэн лю - стиль жизни и мышления. [Электронный ресурс]. Режим доступа: http://anashina.com/fengliu/.

Судникович Ольга. Великая Эпоха (The Epoch Times) [Электронный ресурс]. - Режим доступа: http://www.epochtimes.ru/content/view/79618/34/.

Елисеефф В. Цивилизация классического Китая / В. Елисеефф. Екатеринбург, $2007-640$ с.

История Востока. В 6 т. Т. 2: Восток в средние века / Гл. редкол. : Р. Б. Рыбаков (пред.) и др.; [Отв. ред. Л. Б. Алаев, К. З. Ашрафян]. М.: Восточная литература, 2002. - 716 с.

Классическая поэзия Индии, Китая, Кореи, Вьетнама, Японии. - М., «Художественная литература», 1972. - 925 с.

Малявин В. В. К вопросу о взаимодействии буддизма с китайской традицией / В. В. Малявин // Тезисы Всесоюзной буддологической конференции. М., 1987. - с. 9.

Малявин В. В. О понятии Цин Тань / В. В. Малявин // Общество и государство в Китае. М., 1974. - С. 90-97.

Петров А. А. Ван Би (226-249): Из истории китайской философии / А. А. Петров // Труды ИВ АН СССР. Т.13. - М.-Л.: Изд-во АН. 1936. - 136 с.

Торчинов Е. А. Рационализм в раннесредневековой мысли Китая: философия сюань сюэ / Е. А. Торчинов // Рационалистические традиции и современность. Китай. - М., 1993. - С. 66-86.

Хун Сюпин. «Синтез сюаньсюэ и буддизма, Шесть школ и семь направлений и вклад сочинения Сэн Чжао «Чжаолунь»» (玄佛合流、六家七宗与《肇论》的贡献) / Хун Сюпин // Вестник БНЦ, 2016. - № 3. - c. 68-77.

Янгутов Л. Е. Традиции Праджняпарамиты в Китае / Л. Е. Янгутов. Улан-Удэ: Изд-во Бурят. гос. ун-та, 2007. - 272 с. 